\title{
Lactation performance of dairy cows fed yeast-derived microbial protein in low- and high-forage diets
}

\author{
A. K. Manthey, ${ }^{*}$ K. F. Kalscheur, ${ }^{* 1,2}$ A. D. Garcia, ${ }^{*}$ and K. Mjoun ${ }^{3}$ \\ *Dairy Science Department, South Dakota State University, Brookings 57007 \\ †Alltech Inc., Brookings, SD 57006
}

\begin{abstract}
The objective of this study was to investigate the effect of substituting soybean meal products with yeast-derived microbial protein (YMP) on lactation performance in diets containing 2 forage-to-concentrate ratios. Sixteen Holstein cows (4 primiparous and 12 multiparous) were randomly assigned to multiple $4 \times$ 4 Latin squares with a $2 \times 2$ factorial arrangement of treatments. Diets contained low (LF; $45 \%$ of diet DM) or high forage (HF; $65 \%$ of diet DM) and YMP at 0 (NYMP) or $2.25 \%$ (WYMP) of the diet. The forage mix consisted of $67 \%$ corn silage and $33 \%$ alfalfa hay on a DM basis. No interactions of forage and YMP were noted for any of the production parameters measured. Feed efficiency (energy-corrected milk/dry matter intake) was greater for cows fed NYMP compared with WYMP. Regardless of the addition of YMP, cows fed LF had greater dry matter intake and produced more milk than cows fed HF. In addition, cows fed LF produced more energy-corrected milk than those fed HF. Milk fat percentage was lower in cows fed LF compared with $\mathrm{HF}$, whereas fat yield was similar between forage concentrations. Fat yield tended to decrease with feeding YMP. Interactions of forage and YMP were observed for propionate concentration, acetate and propionate proportion, and acetate-to-propionate ratio. A tendency for an interaction of forage and YMP was also noted for ruminal $\mathrm{pH}$. Cows fed HF diets had greater ruminal ammonia and butyrate concentrations, as well as proportion of butyrate. Arterial concentrations of Ile, Leu, Met, Thr, and Val were greater in cows fed LF. Cows fed NYMP had greater arterial concentrations of Ile, Lys, Trp, and Val than cows fed WYMP. Substitution of soybean proteins with YMP did not improve performance or feed efficiency of high-producing dairy

\footnotetext{
Received June 25, 2015.

Accepted December 5, 2015.

${ }^{1}$ Corresponding author: kenneth.kalscheur@ars.usda.gov

${ }^{2}$ Present address: U. S. Dairy Forage Research Center, USDA-ARS,

${ }^{3}$ Present address: 700 32nd Ave., Brookings, SD 57006.
} 1925 Linden Drive, Madison, WI 53706.
\end{abstract}

cows regardless of the forage-to-concentrate ratio of the diet.

Key words: yeast-derived microbial protein, forageto-concentrate ratio, milk production, dairy cows

\section{INTRODUCTION}

Feed prices are the largest milk production expense, accounting for $53 \%$ of total costs in 2014 (USDA-ERS, 2015). Dairy cow diets should be formulated to meet the MP requirements for milk production by feeding a diet balanced for RDP and RUP that also promotes high N efficiency (Agle et al., 2010). Microbial CP (MCP) has a superior AA profile compared with that in commercial feed ingredients (Clark et al., 1992). The AA requirements of high-producing dairy cows cannot be met by MCP alone. Feeding additional dietary RDP may result in diminishing returns of MCP when ruminal ammonia $\mathrm{N}$ exceeds microbial requirements (Satter and Slyter, 1974). Maintaining adequate RDP in the diet allows for a high-quality source of RUP to be included to improve the quantity of AA reaching the small intestine and support maximum milk protein concentration and yield (Santos et al., 1998; Kalscheur et al., 2006).

New technologies are being developed to find alternative protein supplements to replace traditional feeds, such as soybean meal, fishmeal, and animal protein sources (Seo et al., 2008). These technologies include slow-release urea (Taylor-Edwards et al., 2009), rumenprotected AA (Ordway et al., 2009), oilseeds, oilseed meals that have been chemically or heat-treated (NRC, 2001), and peptides (Gilbert et al., 2008), all of which can improve the total amount as well as the AA profile of the MP reaching the small intestine for absorption (NRC, 2001).

Yeast-derived microbial protein (YMP) is a by-product of yeast fermentation with an AA profile that closely resembles the composition of ruminal microbial protein (Sabbia et al., 2012). Previous studies have shown YMP to be an effective replacement for vegetable proteins in dairy cow diets (Sabbia et al., 2012; Neal et al., 2014). 
Inclusion of YMP in diets with a forage-to-concentrate ratio of 60:40 led to no differences in milk production or ECM/DMI; however, milk production was maintained as dietary YMP concentrations increased from 1.14 to $3.41 \%$ of dietary DM (Sabbia et al., 2012). Neal et al. (2014) conducted a similar study with YMP fed at $1.15 \%$ of diet DM and found a tendency for increased milk production and ECM/DMI.

The amount of forage concentration in the diet influences passage rate of the liquid digesta, with increased liquid passage rate occurring with increased concentrations of forages (Colucci et al., 1982; Ledoux et al., 1985; Jacques et al., 1989; Colucci et al., 1990; Allen, 1996). We hypothesized that YMP flows with the liquid phase in the rumen, allowing for increased absorption of AA in the small intestine. The amount of AA available for absorption may be further increased when YMP is fed as part of high-forage diets that promote greater liquid passage rate, resulting in better lactation performance. Therefore, the objectives of our study were to evaluate the effect of feeding YMP in partial substitution of soybean meal and mechanically extracted soybean meal in diets formulated with varying forage-to-concentrate ratios on DMI, milk production, and components, as well as blood and rumen measures of high-producing dairy cows.

\section{MATERIALS AND METHODS}

\section{Animals and Diets}

This experiment was conducted at the Dairy Research and Training Facility at South Dakota State University (Brookings). All procedures were approved by the South Dakota Institutional Animal Care and Use Committee. Sixteen Holstein dairy cows (12 multiparous and 4 primiparous) averaging $88 \pm 18$ DIM at the beginning of the experiment were used in a $4 \times$ 4 Latin square design with a $2 \times 2$ factorial arrangement of treatments with four 28-d periods. Cows were blocked by parity and milk production with 1 square consisting of 4 ruminally cannulated, multiparous cows. Treatment diets were formulated with YMP (WYMP; $2.25 \%$ of diet DM) or without YMP (NYMP; DEMP; Alltech Inc., Nicholasville, KY) and at 2 forage-toconcentrate ratios, 45:55 (low forage, LF) and 65:35 (high forage, HF). Within each forage-to-concentrate ratio, the forage mix consisted of $67 \%$ corn silage and $33 \%$ alfalfa hay on a DM basis. Yeast-derived microbial protein partially replaced soybean meal, soyhulls, and mechanically extracted soybean meal in LF and HF diets (Table 1). One unit of YMP replaced 0.37, 0.44, and $0.19 \mathrm{U}$ of soybean meal, mechanically extracted soybean meal, and soyhulls, respectively, to maintain constant CP, RDP, and RUP across treatments as estimated by the NRC (2001). Diets were formulated to be isonitrogenous and isoenergetic $(16.2 \% \mathrm{CP}$ and 1.57 $\mathrm{Mcal} / \mathrm{kg}$ of $\mathrm{NE}_{\mathrm{L}}$, respectively).

Forages were premixed in a vertical mixer and blended with concentrates in a Calan Data Ranger (American Calan Inc., Northwood, NH). Cows were individually fed for ad libitum intake once daily (0800 h) using Calan Broadbent individual animal feeders (American Calan Inc.). Orts were weighed once daily and feed offered adjusted for $10 \%$ orts. Week 1 and 2 of each period were used for acclimation to diets, and wk 3 and 4 were for data collection. Cows had unlimited access to water and feed during the day, except during milking. All cows received rbST (Posilac; Monsanto, St. Louis, MO) every $14 \mathrm{~d}$ according to existing farm protocol.

\section{Measurements and Sampling}

Feed intakes and orts for individual cows were recorded once daily. Dry matter concentration of corn silage and alfalfa hay was determined weekly for $24 \mathrm{~h}$ at $105^{\circ} \mathrm{C}$, and diets adjusted to maintain a constant forage-to-concentrate ratio throughout the experiment.

Samples of alfalfa hay, corn silage, concentrate mixes, and TMR of each treatment were collected twice during wk 3 and 4 of each period, frozen, and stored at $-20^{\circ} \mathrm{C}$ until analysis. Samples of individual ingredients were collected from the feed mill each time that the concentrate mixes were prepared. At the end of the study individual feed ingredients were then equally composited by weight into one sample. Additional TMR treatment samples were taken once during wk 3 and 4 to determine particle size and physically effective fiber.

Ruminal fluid was sampled from cannulated cows on d 27 of each period at $0,2,4,6,8,10,12,16$, and 24 $\mathrm{h}$ after feeding. Approximately $50 \mathrm{~mL}$ of rumen fluid were collected from 5 separate locations (cranial and caudal mat, cranial sac, ventral sac, and caudal blind sac). Samples were immediately measured for $\mathrm{pH}$, and 2 aliquots $(10 \mathrm{~mL})$ were acidified with either $200 \mu \mathrm{L}$ of $50 \%$ (vol/vol) sulfuric acid or $2 \mathrm{~mL}$ of $25 \%$ (wt/ vol) metaphosphoric acid and stored at $-20^{\circ} \mathrm{C}$ for later analyses of ammonia and VFA, respectively.

Blood samples were collected from all cows on 2 consecutive days during wk 4 of each period by venipuncture of the coccygeal artery (arterial blood) approximately $3 \mathrm{~h}$ after feeding. Blood was drawn into 10-mL vacutainer tubes containing lithium heparin for $\mathrm{AA}$ and plasma urea $\mathrm{N}$, and a $7-\mathrm{mL}$ vacutainer tube containing sodium fluoride and potassium oxa- 
Table 1. Ingredient composition of the experimental diets ${ }^{1}$

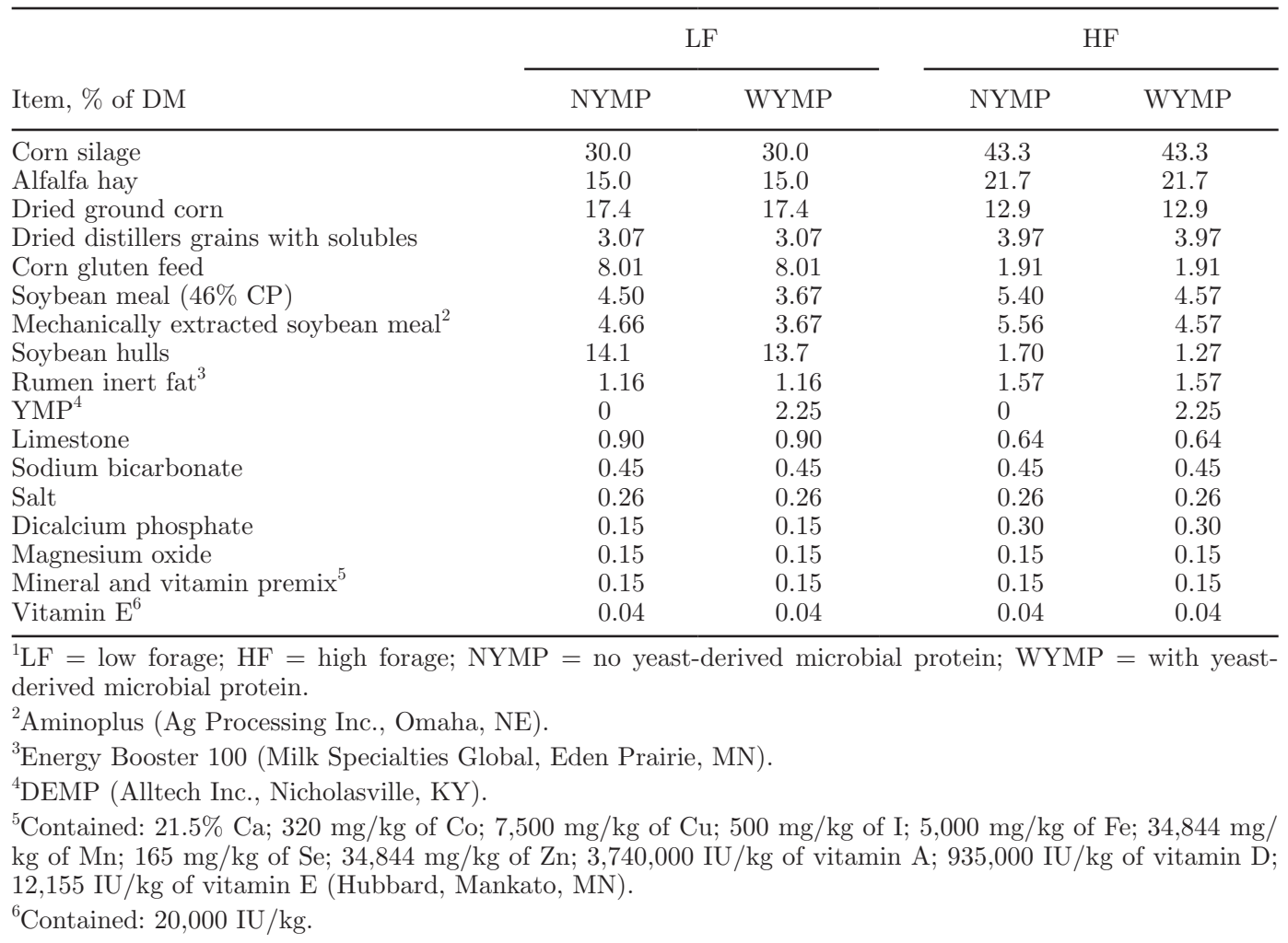

late for glucose (Becton, Dickinson, and Co., Franklin Lakes, NJ). Blood was also collected from the caudal superficial epigastric vein (venous sample) into 10-mL vacutainer tubes containing lithium heparin for AA analysis (Becton, Dickinson, and Co.). Blood samples were centrifuged at $1,000 \times g$ for $20 \mathrm{~min}$ at $5^{\circ} \mathrm{C}(\mathrm{CR} 412$ centrifuge; Jouan Inc., Winchester, VA) and plasma samples were stored at $-20^{\circ} \mathrm{C}$ until analysis.

Cows were milked 3 times daily $(0600,1400$, and $2100 \mathrm{~h}$ ) and milk weights recorded. Milk from individual cows was sampled for component analysis at each milking on 2 consecutive days during wk 3 and 4 . Body weights were recorded on 3 consecutive days at the beginning and end of each period. Body condition score was assessed on a 1-to-5 scale (Wildman et al., 1982) by 3 independent observers at the beginning of the experiment and end of each period.

\section{Laboratory Analysis}

Forage, concentrate, and TMR samples were composited by period, and individual ingredients were composited into 1 sample. Samples were then dried for $48 \mathrm{~h}$ at $55^{\circ} \mathrm{C}$ in a Despatch oven (style V-23; Despatch Oven Co., Minneapolis, MN), ground through a 4-mm screen using a Wiley mill (model 3; Arthur H. Thomas Co.,
Philadelphia, PA), and then further ground through a 1-mm screen (Brinkman ultracentrifuge mill, Brinkman Industries Co., Westbury, NY). Feed composite subsamples were dried at $105^{\circ} \mathrm{C}$ for $3 \mathrm{~h}$ for DM determination (Shreve et al., 2006). Composition analysis was determined at Alltech Laboratories (Alltech Inc., Brookings, SD); NDF was analyzed using sodium sulfite and $\alpha$-amylase (Van Soest et al., 1991) and ADF (Robertson and Van Soest, 1981) sequentially using an Ankom fiber analyzer (Ankom Technology Corp., Macedon, NY). Lignin was determined sequentially on the ADF residue (Van Soest, 1963). Crude protein was determined using an Elementar Rapid N Cube (Elementar, Hanau, Germany; Method 968.06; AOAC International, 2006). Ether extract was determined using an Ankom extractor with diethyl ether as solvent (920.39; AOAC International, 2006). Neutral detergent insoluble $\mathrm{CP}$, acid detergent insoluble $\mathrm{CP}$, and soluble protein were determined according to procedures described by Licitra et al. (1996). Starch content of forages, concentrate mixes, and individual ingredients was determined according to Hall (2009).

A subsample of alfalfa hay, corn silage, concentrate mixes, and individual ingredients was analyzed at Dairyland Laboratories (Arcadia, WI) for minerals (Ca, P, K, Mg, and S) according to AOAC procedures 
(method 953.01; AOAC International, 2006). A second subsample was also sent for a complete AA profile analysis (method 982.30; AOAC International, 2006) to the University of Missouri Agriculture Experiment Station Chemical Laboratories (Columbia, MO). Particle size distribution of the diets was determined by the 4-screen Penn State Particle Separator (Kononoff et al., 2003) using fresh feed samples.

Composites of TMR for each treatment representing samples from all 4 periods were ground to $2 \mathrm{~mm}$ and used for in vitro gas production. Four replicated samples $(0.5 \mathrm{~g})$ weighed in acetone-washed and sealed bags (Ankom F57) were incubated at $39^{\circ} \mathrm{C}$ using 100 $\mathrm{mL}$ of a rumen-buffered inoculum for $48 \mathrm{~h}$ at a rumento-buffer ratio of 1:4. The incubation medium was prepared as described by Mould et al. (2005). Rumen fluid was collected from a high-producing dairy cow fed a typical Midwestern dairy TMR consisting of a 50:50 forage-to-concentrate ratio. Gas production was measured continuously during the incubation period using an automated pressure transducer system. At the end of the incubation period $(48 \mathrm{~h})$, fermentation vessels were depressurized, $\mathrm{pH}$ was measured, and $10 \mathrm{~mL}$ of fluid were collected for VFA analyses. To estimate true DM digestibility, residues of undigested feed were dried and weighed, then treated with a neutral detergent solution with sodium sulfite added (Goering and Van Soest, 1970). Gas production data (576 data points) were fitted to an exponential model: $\mathrm{GP}=\mathrm{a} \times 1-$ $\operatorname{Exp}[-\mathrm{b} \times(\mathrm{t}-\mathrm{c})]$; where a represents the asymptotic gas production $(\mathrm{mL}), \mathrm{b}$ the fractional degradation rate $\left(\mathrm{h}^{-1}\right)$, c represents lag time $(\mathrm{h})$, and t represents time.

Rumen fluid and in vitro samples were thawed, centrifuged at $15,000 \times g$ for $15 \mathrm{~min}$ at $4^{\circ} \mathrm{C}$, and then analyzed for VFA concentrations. Ethyl butyrate was used as the internal standard. Analyses were conducted on a 7890A gas chromatograph equipped with a 7693 auto sampler and a flame-ionization detector (Agilent Technologies, Hewlett Packard, Palo Alto, CA). Peaks were separated using a $25-\mathrm{m} \times 150-\mu \mathrm{m} \times 0.25-\mu \mathrm{m}$ capillary column (Agilent CP 7686). Initial oven temperature was $90^{\circ} \mathrm{C}$, increased to $180^{\circ} \mathrm{C}$ by $15^{\circ} \mathrm{C} / \mathrm{min}$, then by $90^{\circ} \mathrm{C} / \mathrm{min}$ to $250^{\circ} \mathrm{C}$, and held for $2 \mathrm{~min}$. The injector port was maintained at $270^{\circ} \mathrm{C}$, with a $30: 1$ split ratio. Rumen subsamples reserved for ammonia $\mathrm{N}$ were centrifuged at $10,000 \times g$ for $10 \mathrm{~min}$ at $4^{\circ} \mathrm{C}$ and analyzed as described by Weatherburn (1967).

Plasma samples were composited by cow and period and analyzed for glucose concentrations by glucose oxidase reaction (Trinder, 1969) using a glucose kit (glucose kit, code 301001-081, Pointe Scientific Inc., Canton, MI). Plasma free AA were analyzed by the University of Missouri Agriculture Experiment Station
Chemical Laboratories (Colombia, MO) according to AOAC Official method 982.30 E (1,b; AOAC International, 2006). Arteriovenous difference was calculated for each AA as arterial plasma concentration minus venous plasma concentration (Cant et al., 1993). Extraction efficiency was calculated as extraction efficiency $(\%)=$ arteriovenous difference/arterial concentration $\times 100$. Amino acids were classified into EAA and NEAA based on their importance for milk protein synthesis (Clark et al., 1978). The EAA were Arg, His, Ile, Leu, Lys, Met, Phe, Thr, Trp, and Val; NEAA were Ala, Asn, Asp, Cys, Gln, Glu, Gly, Pro, Ser, and Tyr; and branchedchain AA (BCAA) were Ile, Leu, and Val. Total AA was calculated as the sum of EAA and NEAA.

Milk samples were sent to Heart of America DHIA Laboratory (Manhattan, KS) for composition analysis. Fat, protein, and lactose were analyzed via midinfrared spectroscopy (AOAC International, 2006; Bentley 2000 Infrared Milk Analyzer, Bentley Instruments, Chaska, MN). Milk urea nitrogen was determined using a modified Berthelot reaction (ChemSpec 150 Analyzer, Bentley Instruments). Somatic cells were counted using laser technology (Soma Count 500, Bentley Instruments).

\section{Statistical Analysis}

All data were analyzed using the MIXED procedure in SAS version 9.3 (SAS Institute Inc., Cary, NC). Weekly means of DMI and milk yield during the final 2 wk of each period were used for statistical analysis. Means for milk composition were determined from individual samples taken at each milking twice weekly during wk 3 and 4. Plasma metabolites were from samples collected on 2 consecutive days during wk 4, BW from 3 consecutive days at the beginning and end of each period, and BCS at the beginning and end of each period. These data were averaged and analyzed using the following model:

$$
\begin{gathered}
\mathrm{Y}_{\mathrm{ijklm}}=\mu+\text { Forage }_{\mathrm{i}}+\mathrm{YMP}_{\mathrm{j}}+\left(\text { Forage }_{\mathrm{i}} \times \mathrm{YMP}_{\mathrm{j}}\right) \\
+\mathrm{S}_{\mathrm{k}}+\left(\text { Forage }_{\mathrm{i}} \times \mathrm{S}_{\mathrm{k}}\right)+\left(\mathrm{YMP}_{\mathrm{j}} \times \mathrm{S}_{\mathrm{k}}\right) \\
+\left(\text { Forage }_{\mathrm{i}} \times \mathrm{YMP}_{\mathrm{j}} \times \mathrm{S}_{\mathrm{k}}\right)+\mathrm{P}_{1}+\mathrm{C}_{\mathrm{m}(\mathrm{Sk})}+\varepsilon_{\mathrm{ijklm}}
\end{gathered}
$$

where $Y_{\mathrm{ijklm}}$ is the dependent variable, $\mu$ is the overall mean, Forage $_{\mathrm{i}}$ is the effect of forage level $\mathrm{i}$ ( $\mathrm{i}=1$ to 2 ), $\mathrm{YMP}_{\mathrm{j}}$ is the effect of YMP $\mathrm{j}(\mathrm{j}=1$ to 2$)$, $\left(\right.$ Forage $_{\mathrm{i}} \times$ $\mathrm{YMP}_{\mathrm{j}}$ ) is the effect of the interaction of forage level $\mathrm{i}$ and YMP level $\mathrm{j}, \mathrm{S}_{\mathrm{k}}$ is the effect of square $\mathrm{k}(\mathrm{k}=1$ to 4), $\mathrm{P}_{1}$ is the effect of period $\mathrm{l}(\mathrm{l}=1$ to 4$), \mathrm{C}_{\mathrm{m}(\mathrm{Sk})}$ is the effect of cow $\mathrm{m}(\mathrm{m}=1$ to 4$)$ nested within square $\mathrm{k}$, and $\varepsilon_{\mathrm{ijk} k \mathrm{~m}}$ is the residual error. The experimental design 
used cow as experimental unit and cow (square) as the random variable.

A repeated measures model was used to evaluate ruminal parameters $\left(\mathrm{pH}, \mathrm{NH}_{3}-\mathrm{N}\right.$, and VFA concentrations), using the following model:

$$
\begin{gathered}
\mathrm{Y}_{\mathrm{ijkn}}=\mu+\text { Forage }_{\mathrm{i}}+\mathrm{YMP}_{\mathrm{j}}+\left(\text { Forage }_{\mathrm{i}} \times \mathrm{YMP}_{\mathrm{j}}\right) \\
+\mathrm{P}_{\mathrm{k}}+\mathrm{C}_{\mathrm{l}}+\varepsilon_{\mathrm{ijk}}+\mathrm{H}_{\mathrm{n}} \\
+\left(\mathrm{H}_{\mathrm{n}} \times \text { Forage }_{\mathrm{i}} \times \mathrm{YMP}_{\mathrm{j}}\right)+\omega_{\mathrm{ijkn}},
\end{gathered}
$$

where $Y_{\mathrm{ijkn}}$ is the dependent variable, $\mu$ is the overall mean, Forage $e_{i}$ is the effect of forage level $\mathrm{i}(\mathrm{i}=1$ to 2$)$, $\mathrm{YMP}_{\mathrm{j}}$ is the effect of YMP $\mathrm{j}(\mathrm{j}=1$ to 2 ), (Forage $\mathrm{i} \times$ $Y_{\mathrm{M}}$ ) is the effect of the interaction of forage level $\mathrm{i}$ and YMP level $\mathrm{j}, \mathrm{P}_{\mathrm{k}}$ is the effect of period $\mathrm{k}(\mathrm{k}=1$ to 4), $\mathrm{C}_{1}$ is the effect of cow l ( $1=1$ to 4$), \varepsilon_{\mathrm{ijk}}$ is the whole plot error, $H_{n}$ is the effect of time $n(n=1$ to 9$)$, $\left(H_{n}\right.$ $\times$ Forage $\left._{i} \times \mathrm{YMP}_{\mathrm{j}}\right)$ is the interaction between time $\mathrm{n}$, Forage $\mathrm{i}$, and YMP j, and $\omega_{\mathrm{ijkn}}$ is the subplot error. For each variable, the covariance structure corresponding to the lowest value given by the Akaike's information criterion (compound symmetry) was selected (Littell et al., 2006).

In vitro gas production kinetics $(a, b)$, total DM digestibility, NDF digestibility, $\mathrm{pH}$, and VFA profile were analyzed using the following model:

$$
\begin{aligned}
& \mathrm{Y}_{\mathrm{ijk}}=\mu+\text { Forage }_{\mathrm{i}}+\mathrm{YMP}_{\mathrm{j}} \\
& +\left(\text { Forage }_{\mathrm{i}} \times \mathrm{YMP}_{\mathrm{j}}\right)+\varepsilon_{\mathrm{ijk}},
\end{aligned}
$$

where $Y_{i j k}$ is the dependent variable, $\mu$ is the overall mean, Forage $_{i}$ is the effect of forage level $\mathrm{i}$ ( $\mathrm{i}=1$ to 2 ), $\mathrm{YMP}_{\mathrm{j}}$ is the effect of YMP $\mathrm{j}(\mathrm{j}=1$ to 2$)$, (Forage $\mathrm{i} \times$ $\left.Y_{\mathrm{M}}\right)$ is the effect of the interaction of forage level $\mathrm{i}$ and YMP level $\mathrm{j}$, and $\varepsilon_{\mathrm{ijk}}$ is the residual error.

All data are presented as least squares means and separation of treatment means where interactions were found was completed using the Tukey's test. Interactions that were deemed not significant $(P \geq 0.05)$ were removed from the models. Significance was declared at $P \leq 0.05$ and tendencies were declared at $0.05<P \leq$ 0.10 .

\section{RESULTS}

\section{Nutrient Composition of Diets}

Dietary nutrient concentrations were calculated based on individual ingredient analysis (Table 2). Concentrations of $\mathrm{CP}, \mathrm{NDF}$, ADF, lignin, starch, ether extract, ash, and $\mathrm{NE}_{\mathrm{L}}$ were similar across diets and averaged
$16.0,32.4,19.1,2.52,24.3,3.20,5.33$, and $1.59 \mathrm{Mcal} /$ $\mathrm{kg}$ (on a DM basis), respectively. The analyzed nutrient composition of the individual ingredients is presented in Table 3. Slight differences in the AA concentration between YMP and soybean proteins were measured. The YMP had numerically greater concentrations of Ile, Lys, Met, Thr, and Val, and lower concentrations of Arg, His, Phe, and Trp compared with soybean meal. The experimental diets were similar in AA concentration across forage concentration (LF vs. HF) regardless of the addition of YMP (Table 4), except for small increases in Lys and Met (\% of MP) in the diets with added YMP. However, these differences are unlikely to have significant effects on lactation performance.

Particle size of the diets showed no differences due to the addition of YMP (Table 5). However, as expected, differences were noted between forage-to-concentrate ratios for each screen. The particle size data provides important information considering the hypothesis with regard to forage-to-concentrate ratio and passage rate. More particles were retained on the 1.8-mm screen and bottom pan in LF compared with $\mathrm{HF}$, at 32.7 vs. 31.6 and 31.0 vs. $23.5 \%$, respectively $(P<0.001)$.

\section{Production Measures}

Lactation responses to feeding different forage-toconcentrate ratios and YMP are presented in Table 6 . No significant forage $\times$ YMP interactions were observed for any of the reported animal performance measures except for $\mathrm{N}$ efficiency. Dry matter intake was not affected by YMP; however, it was affected by forage-toconcentrate ratio $(P<0.001)$. Cows fed LF consumed approximately $1.6 \mathrm{~kg} / \mathrm{d}$ more DM than cows fed HF. Milk production was also not affected by the inclusion of YMP; however, milk production was greater for cows fed LF than for those fed HF (40.1 and $37.8 \mathrm{~kg} / \mathrm{d}$, respectively).

The inclusion of YMP resulted in no differences in milk fat or protein percentage among treatments; however, forage concentration affected milk components. Milk fat percentage was greater $(P=0.04)$ in cows fed HF compared with those fed LF diets. Due to lower milk yield in $\mathrm{HF}$-fed cows, fat yield was similar for cows fed different forage-to-concentrate ratios, but tended $(P$ $=0.07)$ to be lower for cows fed YMP compared with those fed NYMP. Whereas protein and lactose percentage were similar regardless of diet, protein and lactose yield were greater in cows fed LF compared with those fed HF $(P<0.001)$. Cows fed LF had a lower MUN than cows fed HF diets $(P<0.01)$.

Feed efficiency (ECM/DMI) was greater in cows fed NYMP compared with those fed WYMP, regard- 
MANTHEY ET AL.

Table 2. Analyzed nutrient composition of the experimental diets ${ }^{1}$

\begin{tabular}{|c|c|c|c|c|}
\hline \multirow{2}{*}{$\begin{array}{l}\text { Item, \% of DM } \\
\text { (unless otherwise noted) }\end{array}$} & \multicolumn{2}{|c|}{$\mathrm{LF}$} & \multicolumn{2}{|c|}{$\mathrm{HF}$} \\
\hline & NYMP & WYMP & NYMP & WYMP \\
\hline DM, \% & 62.3 & 62.4 & 55.1 & 55.1 \\
\hline $\mathrm{CP}$ & 16.1 & 16.0 & 16.0 & 16.0 \\
\hline $\mathrm{RDP}^{2}$ & 9.9 & 9.9 & 9.9 & 9.9 \\
\hline $\mathrm{RUP}^{2}$ & 6.2 & 6.2 & 6.2 & 6.2 \\
\hline Soluble protein, $\%$ of $\mathrm{CP}$ & 44.8 & 43.9 & 44.7 & 43.8 \\
\hline MP balance, ${ }^{2} \mathrm{~g} / \mathrm{d}$ & 32 & 29 & 33 & 28 \\
\hline NDIN & 3.08 & 3.10 & 3.02 & 3.11 \\
\hline ADIN & 0.73 & 0.70 & 0.73 & 0.72 \\
\hline $\mathrm{NE}_{\mathrm{L}},{ }^{2} \mathrm{Mcal} / \mathrm{kg}$ & 1.59 & 1.59 & 1.59 & 1.59 \\
\hline $\mathrm{NDF}$ & 33.7 & 32.2 & 32.1 & 31.6 \\
\hline Forage NDF & 18.5 & 18.5 & 26.8 & 26.8 \\
\hline $\mathrm{ADF}$ & 20.0 & 18.9 & 18.8 & 18.5 \\
\hline Lignin & 2.23 & 2.56 & 2.66 & 2.65 \\
\hline Starch & 24.0 & 24.3 & 24.4 & 24.5 \\
\hline $\mathrm{NFC}^{3}$ & 41.7 & 43.3 & 43.3 & 43.9 \\
\hline Ether extract & 3.15 & 3.20 & 3.22 & 3.22 \\
\hline Ash & 5.31 & 5.32 & 5.37 & 5.32 \\
\hline $\mathrm{Ca}$ & 0.88 & 0.87 & 0.87 & 0.86 \\
\hline $\mathrm{P}$ & 0.38 & 0.40 & 0.37 & 0.39 \\
\hline $\mathrm{Mg}$ & 0.39 & 0.39 & 0.39 & 0.38 \\
\hline $\mathrm{K}$ & 1.14 & 1.11 & 1.08 & 1.05 \\
\hline $\mathrm{S}$ & 0.25 & 0.25 & 0.21 & 0.21 \\
\hline
\end{tabular}

less of forage-to-concentrate ratio. No effect of YMP or forage-to-concentrate ratio was observed for $\mathrm{BW}$ or BW change. An effect of forage on BCS $(P=0.05)$ and BCS change $(P=0.05)$ was seen, with cows fed LF having a greater BCS than those fed HF (3.09 vs. 3.04, respectively).

\section{Rumen Fermentation Measures}

Rumen fermentation measures are presented in Table 7. The inclusion of YMP resulted in increased ruminal butyrate proportion. An increased forage-to-concentrate ratio of the diet increased ruminal concentrations of ammonia, isobutyrate, butyrate, isovalerate, and the molar proportions of acetate, isobutyrate, butyrate, isovalerate, and the ratio of acetate to propionate. Inversely, molar concentration and proportion of propionate decreased with increasing dietary forage-to-concentrate ratio. No changes in total VFA concentrations were observed as a result of the inclusion of YMP or increasing dietary forage-to-concentrate ratio, suggesting similar rumen fermentability. In fact, all diets contained similar starch and NFC concentration. However, in vitro DM and NDF digestibility were greater in LF compared with HF diets (Table 8). Gas production extent was also greater in LF compared with HF diets, whereas rate $(\% / \mathrm{h})$ was greater for HF compared with LF diets.

\section{Plasma Metabolites and AA Profiles}

Plasma metabolite concentrations are presented in Table 9. No effects of YMP or forage-to-concentrate ratio on plasma glucose concentrations were noted; also, no effect of YMP inclusion on plasma urea N concentration was seen. However, cows fed HF diets had greater plasma urea $\mathrm{N}$ concentrations than cows fed $\mathrm{LF}$ diets.

Arterial concentrations of EAA are presented in Table 10. No forage $\times$ YMP interactions were observed for arterial concentrations of AA. The profile of plasma AA has been used as an indicator of metabolizable AA used for milk protein synthesis (Doepel et al., 2004). Cows fed YMP had lower concentrations of EAA and BCAA $(P<0.05)$. Feeding YMP resulted in lower concentrations of Ile, Lys, Trp, and Val and a tendency for lower concentrations of Arg, His, Leu, and Thr, despite similar dietary AA concentrations for the WYMP and NYMP diets.

The arteriovenous difference of AA is presented in Table 10. The addition of YMP had no effect on arteriovenous difference of $\mathrm{AA}$. The arteriovenous differences of Arg, Ile, Leu, Lys, Met, Phe, Thr, and EAA ( $P$ $<0.05)$ and Val $(P=0.06)$ were greater in cows fed LF compared with cows fed HF, suggesting more of these EAA were available for absorption compared with $\mathrm{HF}$ 


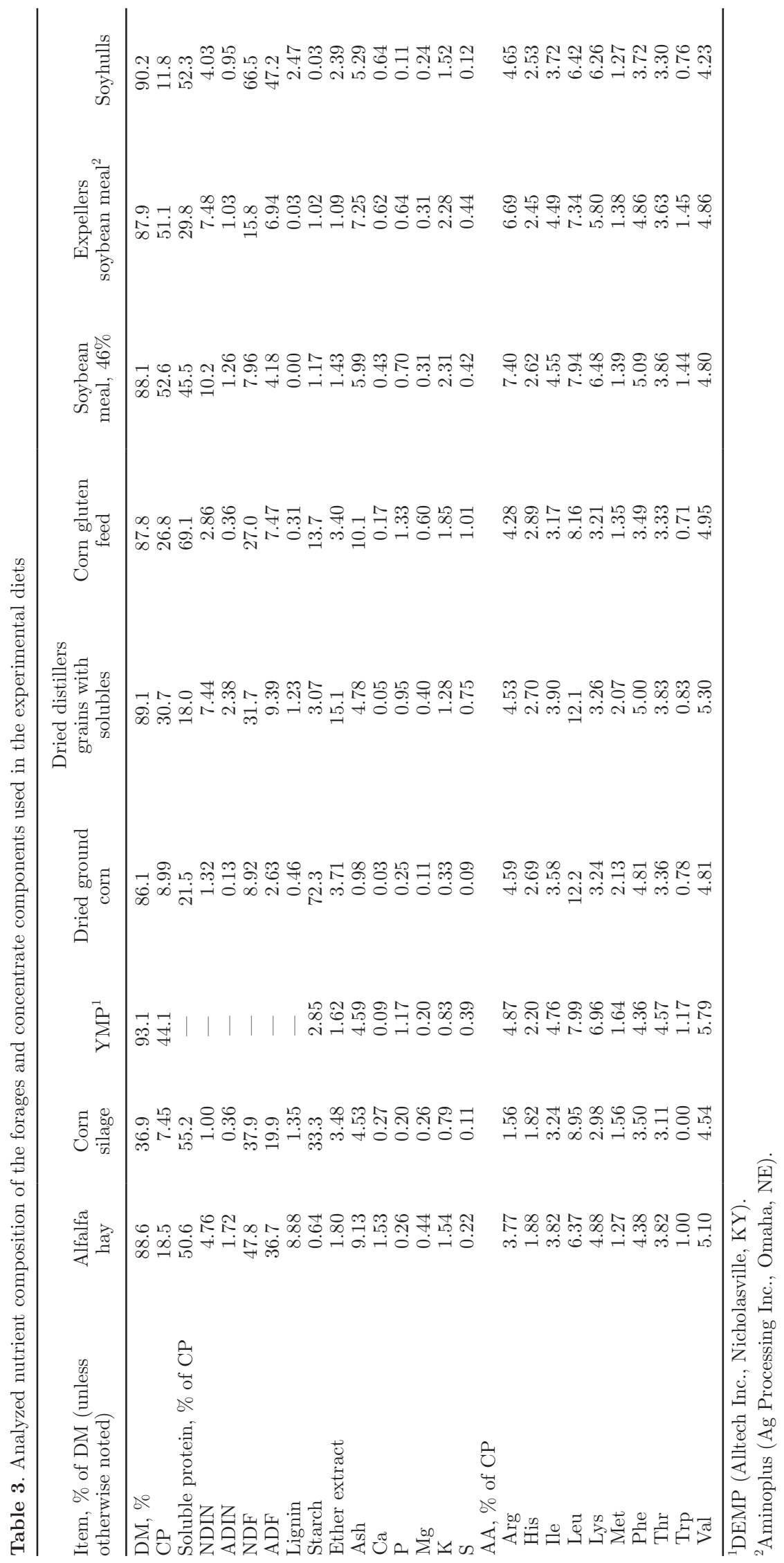


Table 4. Analyzed AA composition of the experimental diets ${ }^{1}$

\begin{tabular}{|c|c|c|c|c|}
\hline \multirow{2}{*}{$\begin{array}{l}\text { AA, } \% \text { of CP } \\
\text { (unless otherwise noted) }\end{array}$} & \multicolumn{2}{|c|}{$\mathrm{LF}$} & \multicolumn{2}{|c|}{$\mathrm{HF}$} \\
\hline & NYMP & WYMP & NYMP & WYMP \\
\hline Arg & 4.13 & 4.07 & 4.07 & 3.72 \\
\hline His & 2.33 & 2.26 & 2.26 & 2.11 \\
\hline Ile & 3.79 & 3.67 & 3.67 & 3.68 \\
\hline Leu & 8.37 & 8.41 & 8.41 & 8.38 \\
\hline Lys & 4.40 & 4.43 & 4.43 & 4.21 \\
\hline Met & 1.51 & 1.52 & 1.52 & 1.49 \\
\hline Phe & 4.17 & 4.16 & 4.16 & 4.19 \\
\hline Thr & 3.47 & 3.60 & 3.60 & 3.49 \\
\hline Trp & 0.70 & 0.59 & 0.59 & 0.61 \\
\hline Val & 4.88 & 4.71 & 4.71 & 4.73 \\
\hline Total EAA & 37.7 & 37.4 & 37.4 & 36.6 \\
\hline Lys, $^{2} \%$ of MP & 5.89 & 6.01 & 5.81 & 5.94 \\
\hline Met, ${ }^{2} \%$ of MP & 1.70 & 1.72 & 1.68 & 1.71 \\
\hline
\end{tabular}

${ }^{1} \mathrm{LF}=$ low forage; $\mathrm{HF}=$ high forage; NYMP $=$ no yeast-derived microbial protein; WYMP = with yeastderived microbial protein. Dietary AA concentrations were calculated based on their concentrations in the individual ingredients and the relative proportion of individual ingredients in the diets.

${ }^{2}$ Estimated from NRC (2001).

fed cows. No differences in extraction efficiency were noted (data not shown).

\section{DISCUSSION}

Contrary to the pretrial hypothesis, the inclusion of YMP in HF diets did not improve production. Sabbia et al. (2012) reported that YMP had an EAA profile similar to that of MCP, and contained greater concentrations of Met and Lys than soybean meal, both considered to be the most limiting AA in milk production (Schwab et al., 1992; Sabbia et al., 2012). In the current experiment, the inclusion of YMP resulted in little differences in AA between treatments when RDP and RUP were held constant. This lack of difference in AA between treatments, and apparently adequate supply of MP as suggested by NRC (2001), likely explains the lack of production responses in diets in which YMP was included.

Dry matter intake was not expected to be influenced by the inclusion of YMP in diets. Sabbia et al.
(2012) found that DMI was greatest when cows were fed YMP at 1.14 and $3.41 \%$ of DM. The reason for this increase in DMI could not be explained and was attributed to the greater NDF digestibility of those diets. In the current study, no differences were noted in in vitro NDF digestibility as a result of the inclusion of YMP. The increased DMI in LF diets is consistent with previous studies that evaluated diets differing in forage-to-concentrate ratio (Colucci et al., 1982; Yang and Beauchemin, 2007). Decreased DMI of cows fed the HF diet likely results from longer retention time of forage particles restricting the flow of digesta through the gastrointestinal tract (Allen, 1996; Oba and Allen, 1999).

Increased milk production was consistent with greater DMI for cows fed LF compared with cows fed HF. Li et al. (2012) fed diets containing 35:65 and 60:40 forageto-concentrate ratios and reported that cows fed diets lower in forage produced more milk (28.8 vs. $25.9 \mathrm{~kg} / \mathrm{d}$, respectively). The decrease in milk production in $\mathrm{HF}$ diets was attributed to decreased energy balance, or po-

Table 5. Particle distribution and physically effective fiber using the Penn State Particle Separator of the experimental diets ${ }^{1}$

\begin{tabular}{|c|c|c|c|c|c|c|c|c|}
\hline \multirow[b]{2}{*}{ Screen, ${ }^{2} \%$ retained on each sieve } & \multicolumn{2}{|c|}{$\mathrm{LF}$} & \multicolumn{2}{|c|}{$\mathrm{HF}$} & \multirow[b]{2}{*}{ SEM } & \multicolumn{3}{|c|}{ Effect $^{3}(P$-value $)$} \\
\hline & NYMP & WYMP & NYMP & WYMP & & $\mathrm{F}$ & YMP & $\mathrm{F} \times \mathrm{YMP}$ \\
\hline Upper $(19 \mathrm{~mm})$ & 4.62 & 4.00 & 6.89 & 6.55 & 0.82 & $<0.001$ & 0.57 & 0.86 \\
\hline Middle ( $8 \mathrm{~mm})$ & 32.0 & 32.0 & 37.8 & 38.5 & 0.80 & $<0.001$ & 0.63 & 0.64 \\
\hline Lower (1.8 mm) & 32.2 & 33.1 & 31.5 & 31.7 & 0.80 & $<0.001$ & 0.49 & 0.67 \\
\hline Bottom pan & 31.1 & 30.9 & 23.8 & 23.2 & 1.12 & $<0.001$ & 0.68 & 0.87 \\
\hline
\end{tabular}

${ }^{1} \mathrm{LF}=$ low forage; HF = high forage; NYMP = no yeast-derived microbial protein; WYMP = with yeast-derived microbial protein.

${ }^{2}$ Particle size distribution of diets was measured using the Penn State Particle Separator (Kononoff et al., 2003).

${ }^{3} \mathrm{~F}=$ effect of forage:concentrate ratio (LF vs. HF); YMP $=$ effect of yeast-derived microbial protein $(\mathrm{NYMP}$ vs. WYMP); $\times$ YMP $=$ the interaction of forage and yeast-derived microbial protein. 
Table 6. Lactation performance of cows fed the experimental diets ${ }^{1}$

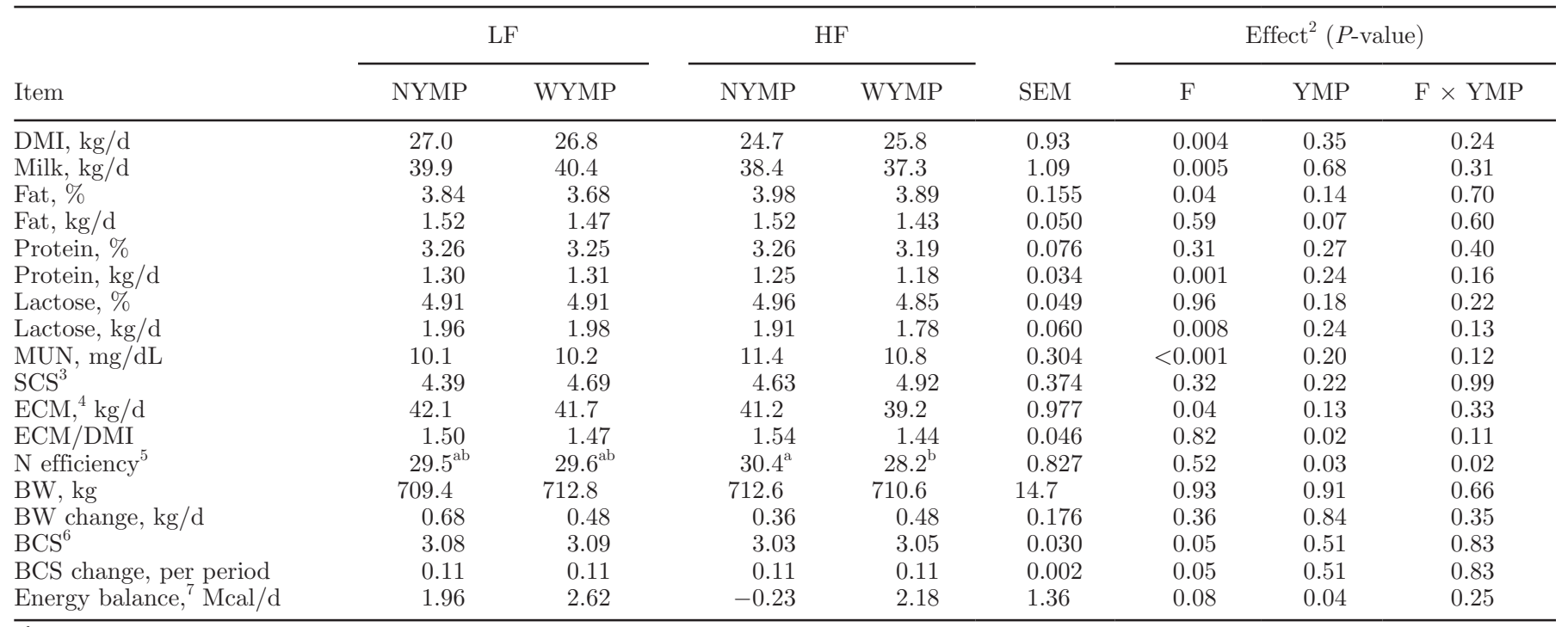

${ }_{\mathrm{a}, \mathrm{b}}$ Means within a row with different superscripts differ significantly $(P<0.05)$.

${ }^{1} \mathrm{LF}=$ low forage; $\mathrm{HF}=$ high forage; NYMP $=$ no yeast-derived microbial protein; WYMP $=$ with yeast-derived microbial protein.

${ }^{2} \mathrm{~F}=$ effect of forage-to-concentrate ratio (LF vs. HF); YMP $=$ effect of yeast-derived microbial protein $(\mathrm{NYMP}$ vs. WYMP); $\times$ YMP $=$ the interaction of forage and yeast-derived microbial protein.

${ }^{3} \mathrm{SCS}=\log (\mathrm{SCC})$.

${ }^{4} \mathrm{ECM}=[0.327 \times$ milk yield $(\mathrm{kg})]+[12.95 \times$ fat yield $(\mathrm{kg})]+[7.2 \times$ protein yield $(\mathrm{kg})]$.

${ }^{5} \mathrm{~N}$ efficiency $=$ milk $\mathrm{N}(\mathrm{kg} / \mathrm{d}) / \mathrm{N}$ intake $(\mathrm{kg} / \mathrm{d}) \times 100$.

${ }^{6} 1=$ emaciated to $5=$ obese (Wildman et al., 1982).

${ }^{7}$ Net energy balance $=\mathrm{NE}_{\mathrm{L}}$ Total $-\left(\mathrm{NE}_{\mathrm{M}}+\mathrm{NE}_{\mathrm{L}}+\mathrm{NE}_{\text {Growth }}\right), \mathrm{NRC}(2001)$.

tentially lower total-tract digestibility of OM. However, in the current experiment, the $1.65 \mathrm{~kg} / \mathrm{d}$ increase in DMI for cows fed LF diets likely explains the increase in milk production.
The lack of differences in AA between treatments may have also played a role in the lack of a response in milk production. This could be further confounded by the concentration of soybean hulls in the diets. The

Table 7. Ruminal $\mathrm{pH}, \mathrm{NH}_{3}$, and VFA concentrations of cows fed the experimental diets ${ }^{1}$

\begin{tabular}{|c|c|c|c|c|c|c|c|c|}
\hline \multirow[b]{2}{*}{ Rumen measure } & \multicolumn{2}{|c|}{$\mathrm{LF}$} & \multicolumn{2}{|c|}{$\mathrm{HF}$} & \multirow[b]{2}{*}{ SEM } & \multicolumn{3}{|c|}{ Effect $^{2}(P$-value $)$} \\
\hline & NYMP & WYMP & NYMP & WYMP & & $\mathrm{F}$ & YMP & $\mathrm{F} \times \mathrm{YMP}$ \\
\hline $\mathrm{pH}$ & 6.05 & 5.95 & 5.97 & 6.01 & 0.132 & 0.74 & 0.46 & 0.09 \\
\hline $\mathrm{NH}_{3}-\mathrm{N}, \mathrm{mg} / \mathrm{dL}$ & 7.25 & 6.90 & 8.65 & 8.29 & 1.22 & 0.006 & 0.48 & 0.99 \\
\hline Acetate, $\mathrm{m} M$ & 55.2 & 53.3 & 55.0 & 56.5 & 2.38 & 0.19 & 0.85 & 0.15 \\
\hline Propionate, $\mathrm{m} M$ & $16.5^{\mathrm{b}}$ & $18.5^{\mathrm{a}}$ & $16.6^{\mathrm{b}}$ & $15.2^{\mathrm{b}}$ & 1.66 & 0.002 & 0.40 & 0.002 \\
\hline Isobutyrate, $\mathrm{m} M$ & 0.65 & 0.65 & 0.71 & 0.73 & 0.040 & $<0.001$ & 0.56 & 0.59 \\
\hline Butyrate, $\mathrm{m} M$ & 8.02 & 8.31 & 8.58 & 8.95 & 0.526 & 0.008 & 0.14 & 0.86 \\
\hline Isovalerate, $\mathrm{m} M$ & 1.21 & 1.23 & 1.41 & 1.46 & 0.216 & $<0.001$ & 0.32 & 0.66 \\
\hline Valerate, $\mathrm{m} M$ & 1.09 & 1.11 & 1.09 & 1.19 & 0.076 & 0.941 & 0.51 & 0.97 \\
\hline Total VFA, $\mathrm{m} M$ & 82.7 & 83.1 & 83.4 & 84.2 & 4.66 & 0.63 & 0.75 & 0.92 \\
\hline Acetate, $\%$ & $66.9^{\mathrm{a}}$ & $64.7^{\mathrm{b}}$ & $66.4^{\mathrm{a}}$ & $67.4^{\mathrm{a}}$ & 1.12 & 0.009 & 0.06 & $<0.001$ \\
\hline Propionate, $\%$ & $19.8^{\mathrm{b}}$ & $21.7^{\mathrm{a}}$ & $19.6^{\mathrm{b}}$ & $18.1^{\mathrm{c}}$ & 0.97 & $<0.001$ & 0.40 & $<0.001$ \\
\hline Isobutyrate, $\%$ & 0.80 & 0.80 & 0.89 & 0.90 & 0.018 & $<0.001$ & 0.59 & 0.77 \\
\hline Butyrate, \% & 9.68 & 9.94 & 10.19 & 10.54 & 0.161 & $<0.001$ & 0.01 & 0.71 \\
\hline Isovalerate, $\%$ & 1.45 & 1.48 & 1.69 & 1.73 & 0.168 & $<0.001$ & 0.26 & 0.73 \\
\hline Valerate, \% & 1.30 & 1.30 & 1.29 & 1.30 & 0.041 & 0.87 & 0.87 & 0.86 \\
\hline Acetate-to-propionate & $3.47^{\mathrm{b}}$ & $3.08^{\mathrm{c}}$ & $3.43^{\mathrm{b}}$ & $3.75^{\mathrm{a}}$ & 0.203 & $<0.001$ & 0.55 & $<0.001$ \\
\hline
\end{tabular}

${ }^{\mathrm{a}-\mathrm{c}}$ Means within a row with different superscripts differ significantly $(P<0.05)$.

${ }^{1} \mathrm{LF}=$ low forage; $\mathrm{HF}=$ high forage; NYMP $=$ no yeast-derived microbial protein; WYMP $=$ with yeast-derived microbial protein.

${ }^{2} \mathrm{~F}=$ effect of forage-to-concentrate ratio (LF vs. HF); YMP = effect of yeast-derived microbial protein $(\mathrm{NYMP}$ vs. WYMP); F $\times$ YMP $=$ the interaction of forage and yeast-derived microbial protein. 
Table 8 . In vitro gas production kinetics and digestibility of cows fed the experimental diets ${ }^{1}$

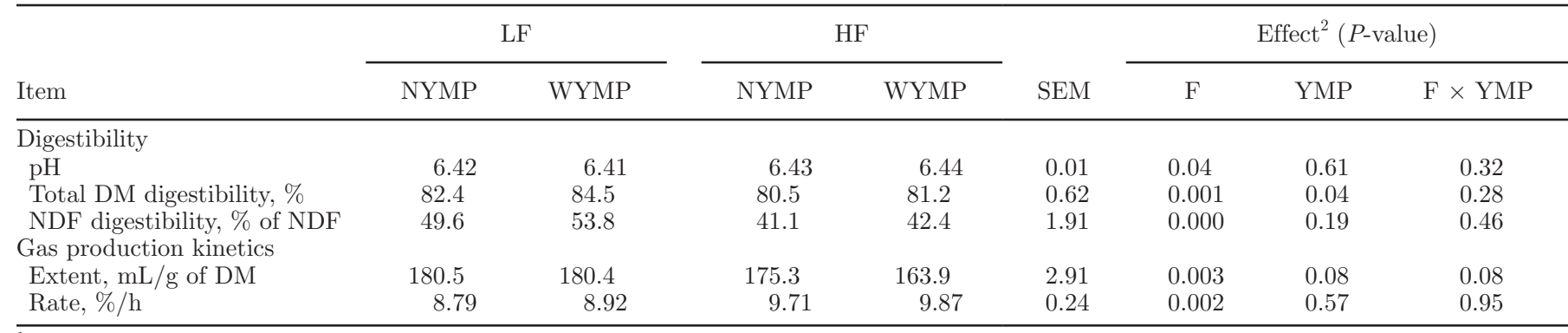

${ }^{1} \mathrm{LF}=$ low forage; $\mathrm{HF}=$ high forage; NYMP = no yeast-derived microbial protein; WYMP = with yeast-derived microbial protein.

${ }^{2} \mathrm{~F}=$ effect of forage-to-concentrate ratio (LF vs. HF); YMP $=$ effect of yeast-derived microbial protein $(\mathrm{NYMP}$ vs. WYMP); F $\times$ YMP $=$ the interaction of forage and yeast-derived microbial protein.

YMP was hypothesized to associate with the liquid phase of the rumen and achieve a high rate of passage in the HF diets. However, the HF diets also contained a lesser concentration of soybean hulls, which is associated with a greater passage rate (Firkins and Eastridge, 1992; Grant, 1997). Therefore, the YMP and soybean hulls may have interacted in the LF diets, resulting in a greater rate of passage from the rumen.

Differences in milk fat percentage between forageto-concentrate ratios could be explained by differences in ruminal fermentation such that cows fed HF had a greater molar proportion of acetate and butyrate. Acetate and butyrate produced in rumen fermentation of carbohydrates are the major carbon sources used in milk fat synthesis in ruminants and their reductions limits milk fat synthesis (Bauman and Griinari, 2003; Agle et al., 2010; Li et al., 2012). Similar results were observed by Yang and Beauchemin (2007), where greater milk fat percentage was attributed to increased fiber digestion and utilization when dietary forage-toconcentrate ratio was increased.

The scientific literature often indicates no changes to small increases in milk yield and protein content when dietary protein, AA, or energy are supplemented (Bequette et al., 1998). This is especially true when energy and protein are not limiting production and the energy balance is at least $+1.0 \mathrm{Mcal} / \mathrm{d}$ and protein supplied by RUP and MCP to the small intestine is at least $+248 \mathrm{~g} / \mathrm{d}$ (Brun-Lafleur et al., 2010). In the present study, because milk protein concentration remained unchanged, the increase in milk yield in LF was likely the result of greater DMI, and consequently increased the supply of ME and protein.

It is difficult to interpret the reason for the decrease in feed efficiency with the inclusion of YMP, particularly when Sabbia et al. (2012) reported no effects of feeding YMP up to $3.41 \%$ of the DM on feed efficiency. In addition, Neal et al. (2014) reported greater feed efficiency for cows fed YMP included at $1.15 \%$ of dietary DM.

The changes in the molar proportions of rumen VFA reported in our study are in agreement with previous studies that evaluated diets with differing forageto-concentrate ratios (Penner et al., 2009; Yang and Beauchemin, 2009). Yang and Beauchemin (2009) reported lower VFA concentration and greater rumen $\mathrm{pH}$ when the forage-to-concentrate ratio was increased from 35 to $60 \%$ of diet DM. Volatile fatty acid production was reduced in their study because of less starch available for fermentation. No effect of YMP on rumen fermentation was present in the present study except for an increase in molar proportion of butyrate and a tendency for acetate to also increase.

Plasma AA concentrations were consistent with other values found in the literature (Yeo et al., 2003; Mjoun et al., 2010). Lysine and Met are the 2 most limiting

Table 9. Plasma metabolites of cows fed the experimental diets ${ }^{1}$

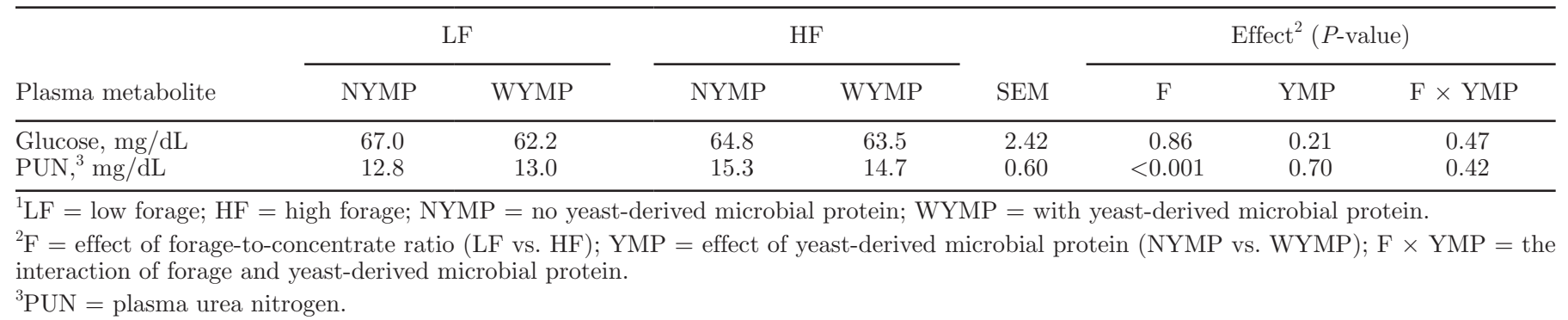


AA for milk production (Schwab et al., 1992). In this experiment, arterial concentrations of Lys and Met were greater for cows fed LF and Lys was greater for cows fed NYMP. Consequently, milk protein remained unchanged whereas protein yield decreased with HF concentrations. Similar milk protein percentage may indicate that the mammary gland was able to maintain milk protein synthesis via increased extraction efficiency of Lys and Met.

Cows fed LF diets had greater arteriovenous differences of EAA, BCAA, and total AA than cows fed HF (Table 10). These changes are consistent with the differences in dietary concentrations of these AA. Limited research is available for comparison that evaluates plasma AA response to feeding different forage-to-concentrate ratios. Few researchers have investigated the effects of feeding diets differing in forage-to-concentrate ratio on AA supplies and lactation performance using other measures than the arteriovenous difference technique. Consistent with the changes observed in plasma AA profile in response to feeding different forage-toconcentrate ratios in this study, Li et al. (2012) reported greater duodenal flows of all AA, with the exception of Trp, in low- compared with high-forage diets (35 vs. 60\%). Similarly, Hussein et al. (1995) fed beef steers either 70 or $30 \%$ forage based solely on corn silage; they reported that the steers fed $30 \%$ forage had greater concentrations of AA in MCP with the exception of Ile, Leu, Lys, and Phe, which were not affected by forage inclusion (Hussein et al., 1995). However, Yang and Beauchemin (2004) showed little effect of altering the forage inclusion rate from 35 to $55 \%$ in diets based on alfalfa silage and hay, and barley silage on the flows of total AA to the duodenum. In their study, cows fed

Table 10. Arterial plasma AA concentrations and arteriovenous difference for cows fed the experimental diets ${ }^{1}$

\begin{tabular}{|c|c|c|c|c|c|c|c|c|}
\hline \multirow[b]{2}{*}{ Item } & \multicolumn{2}{|c|}{$\mathrm{LF}$} & \multicolumn{2}{|c|}{$\mathrm{HF}$} & \multirow[b]{2}{*}{ SEM } & \multicolumn{3}{|c|}{ Effect $^{2}(P$-value $)$} \\
\hline & NYMP & WYMP & NYMP & WYMP & & $\mathrm{F}$ & YMP & $\mathrm{F} \times \mathrm{YMP}$ \\
\hline \multicolumn{9}{|c|}{ Arterial plasma, $\mu \mathrm{mol} / \mathrm{L}$} \\
\hline \multicolumn{9}{|c|}{ EAA } \\
\hline Arg & 73.2 & 66.6 & 67.8 & 64.0 & 3.04 & 0.14 & 0.06 & 0.60 \\
\hline His & 45.5 & 44.8 & 45.8 & 40.6 & 2.29 & 0.20 & 0.06 & 0.15 \\
\hline Ile & 126.4 & 113.5 & 110.6 & 103.6 & 4.40 & 0.005 & 0.03 & 0.51 \\
\hline Leu & 155.0 & 145.1 & 138.7 & 130.3 & 5.35 & 0.005 & 0.08 & 0.89 \\
\hline Lys & 83.1 & 73.3 & 73.5 & 66.6 & 3.21 & 0.007 & 0.006 & 0.62 \\
\hline Met & 21.5 & 19.7 & 19.0 & 18.2 & 1.02 & 0.03 & 0.13 & 0.60 \\
\hline Phe & 45.9 & 43.7 & 43.3 & 44.0 & 1.52 & 0.41 & 0.56 & 0.29 \\
\hline Thr & 107.4 & 100.7 & 97.8 & 91.5 & 4.88 & 0.01 & 0.08 & 0.96 \\
\hline Trp & 63.2 & 61.9 & 63.3 & 58.2 & 1.83 & 0.15 & 0.01 & 0.13 \\
\hline Val & 255.5 & 237.3 & 229.5 & 213.9 & 9.17 & 0.002 & 0.03 & 0.87 \\
\hline EAA & 976.6 & 906.6 & 889.4 & 830.8 & 31.3 & 0.007 & 0.03 & 0.84 \\
\hline $\mathrm{NEAA}^{3}$ & $1,180.0$ & $1,160.5$ & $1,103.8$ & $1,056.5$ & 35.6 & 0.01 & 0.33 & 0.67 \\
\hline $\mathrm{BCAA}^{4}$ & 536.8 & 495.9 & 478.9 & 447.7 & 18.2 & 0.003 & 0.03 & 0.77 \\
\hline $\mathrm{TAA}^{5}$ & $2,156.6$ & $2,068.1$ & $1,993.2$ & $1,887.2$ & 60.8 & 0.005 & 0.11 & 0.88 \\
\hline \multicolumn{9}{|c|}{$\begin{array}{l}\text { Arteriovenous difference, }{ }^{6} \mu \mathrm{mol} / \mathrm{L} \\
\text { EAA }\end{array}$} \\
\hline Arg & 37.6 & 37.4 & 33.5 & 32.4 & 2.27 & 0.02 & 0.74 & 0.84 \\
\hline His & 18.2 & 18.4 & 17.5 & 16.2 & 1.20 & 0.21 & 0.64 & 0.53 \\
\hline Ile & 51.4 & 49.3 & 45.7 & 41.6 & 2.90 & 0.02 & 0.71 & 0.71 \\
\hline Leu & 76.1 & 73.6 & 68.0 & 62.6 & 3.89 & 0.01 & 0.27 & 0.68 \\
\hline Lys & 55.0 & 51.0 & 48.5 & 44.5 & 2.69 & 0.007 & 0.08 & 0.99 \\
\hline Met & 14.8 & 14.2 & 13.4 & 12.2 & 0.75 & 0.01 & 0.18 & 0.65 \\
\hline Phe & 26.3 & 25.6 & 23.9 & 23.1 & 1.25 & 0.04 & 0.51 & 0.94 \\
\hline Thr & 39.2 & 38.2 & 34.2 & 32.6 & 2.55 & 0.03 & 0.58 & 0.90 \\
\hline $\operatorname{Trp}$ & 15.0 & 14.8 & 16.2 & 12.2 & 1.72 & 0.58 & 0.09 & 0.13 \\
\hline Val & 76.3 & 74.9 & 67.6 & 64.3 & 5.22 & 0.06 & 0.63 & 0.85 \\
\hline EAA & 409.7 & 397.3 & 368.4 & 341.8 & 22.59 & 0.02 & 0.34 & 0.73 \\
\hline NEAA & 356.7 & 351.9 & 328.2 & 296.3 & 26.70 & 0.09 & 0.46 & 0.58 \\
\hline BCAA & 203.7 & 197.8 & 181.3 & 168.5 & 11.77 & 0.02 & 0.40 & 0.76 \\
\hline TAA & 766.5 & 749.2 & 696.6 & 638.1 & 48.31 & 0.05 & 0.39 & 0.64 \\
\hline
\end{tabular}

${ }^{1} \mathrm{LF}=$ low forage; $\mathrm{HF}=$ high forage; NYMP = no yeast-derived microbial protein; WYMP = with yeast-derived microbial protein.

${ }^{2} \mathrm{~F}=$ effect of forage-to-concentrate ratio ( $\mathrm{LF}$ vs. HF); YMP $=$ effect of yeast-derived microbial protein $(\mathrm{NYMP}$ vs. WYMP); F $\times$ YMP $=$ the interaction of forage and yeast-derived microbial protein.

${ }^{3} \mathrm{NEAA}=$ Ala, Asn, Asp, Cys, Gln, Glu, Gly, Pro, Ser, and Tyr.

${ }^{4} \mathrm{BCAA}=$ branched-chain AA (Val, Ile, and Leu).

${ }^{5} \mathrm{TAA}=\mathrm{EAA}+\mathrm{NEAA}$.

${ }^{6}$ Arteriovenous $=$ arterial plasma concentration - venous plasma concentration (Cant et al., 1993). 
high-forage diets produced more microbial AA and contributed less dietary AA compared with cows fed low-forage diets.

\section{CONCLUSIONS}

Contrary to the pretrial hypothesis, the addition of YMP to HF diets did not increase lactation performance. In addition, feed efficiency decreased when cows were fed YMP, but it was not affected by forage concentration. Based upon the limitations of this study, it could not be determined if YMP flows at a high rate of passage with the liquid phase of the rumen to escape rumen fermentation and provide the small intestine with AA to support milk production. This warrants further investigation. Overall, supplementation of YMP versus soybean products did not improve performance of high-producing dairy cows regardless of the forageto-concentrate ratio of the diet.

\section{ACKNOWLEDGMENTS}

The authors thank Alltech Inc. (Lexington, KY) for the financial support for this project, the graduate students and farm personnel at South Dakota State University for their help with sampling and animal care, and the research personnel at Alltech (Brookings, South Dakota) for their assistance with laboratory analysis.

\section{REFERENCES}

Agle, M., A. N. Hristov, S. Zaman, C. Schneider, P. Ndegwa, and V. K. Vaddella. 2010. The effects of ruminally degraded protein on rumen fermentation and ammonia losses from manure in dairy cows. J. Dairy Sci. 93:1625-1637.

Allen, M. S. 1996. Physical constraints on voluntary intake of forages by ruminants. J. Anim. Sci. 74:3063-3075.

AOAC International. 2006. Official Methods of Analysis. 18th ed. AOAC International, Gaithersburg, MD.

Bauman, D. E., and J. M. Griinari. 2003. Nutritional regulation of milk fat synthesis. Annu. Rev. Nutr. 23:203-227.

Bequette, B. J., F. R. C. Backwell, and L. A. Crompton. 1998. Current concepts of amino acid and protein metabolism in the mammary gland of the lactating ruminant. J. Dairy Sci. 81:2540-2559.

Brun-Lafleur, L., L. Delaby, F. Husson, and P. Faverdin. 2010. Predicting energy $\times$ protein interaction on milk yield and milk composition in dairy cows. J. Dairy Sci. 93:4128-4143.

Cant, J. P., E. J. DePeters, and R. L. Baldwin. 1993. Mammary amino acid utilization in dairy cows fed fat and its relationship to milk protein depression. J. Dairy Sci. 76:762-774.

Clark, J. H., T. H. Klusmeyer, and M. R. Cameron. 1992. Microbial protein synthesis and flows of nitrogen fractions to the duodenum of dairy cows. J. Dairy Sci. 75:2304-2323.

Clark, J. H., H. R. Spires, and C. L. Davis. 1978. Uptake and metabolism of nitrogenous components by the lactating mammary gland. Fed. Proc. 37:1233-1238

Colucci, P. E., L. E. Chase, and P. J. Van Soest. 1982. Feed intake, apparent diet digestibility, and rate of particulate passage in dairy cattle. J. Dairy Sci. 65:1445-1456.
Colucci, P. E., G. K. Macleod, W. L. Grovum, I. McMillan, and D. J Barney. 1990. Digesta kinetics in sheep and cattle fed diets with different forage to concentrate ratios at high and low intakes. J. Dairy Sci. 73:2143-2156.

Doepel, L., D. Pacheco, J. J. Kennelly, M. D. Hanigan, I. F. Lopez, and H. Lapierre. 2004. Milk protein synthesis as a function of amino acid supply. J. Dairy Sci. 87:1279-1297.

Firkins, J. L., and M. L. Eastridge. 1992. Replacement of forage or concentrate with combinations of soyhulls, sodium bicarbonate, or fat for lactating dairy cows. J. Dairy Sci. 75:2752-2761.

Gilbert, E. R., E. A. Wong, and K. E. Webb Jr. 2008. Board-invited review: Peptide absorption and utilization: Implications for animal nutrition and health. J. Anim. Sci. 86:2135-2155.

Goering, H. K., and P. J. Van Soest. 1970. Forage Fiber Analysis (apparatus, reagents, procedures and some applications). USDA Agricultural Handbook No. 379. USDA, Washington, DC.

Grant, R. J. 1997. Interactions among forages and nonforage fiber sources. J. Dairy Sci. 80:1438-1446.

Hall, M. B. 2009. Determination of starch, including maltooligosaccharides, in animal feeds: Comparison of methods and a method recommended for AOAC collaborative study. J. AOAC Int. 92:42-49.

Hussein, H. S., N. R. Merchen, and G. C. Fahey Jr. 1995. Composition of ruminal bacteria harvested from steers as influenced by dietary forage level and fat supplementation. J. Anim. Sci. 73:2469-2473.

Jacques, K., D. L. Harmon, W. J. Croom Jr., and W. M. Hagler Jr 1989. Estimating salivary flow and ruminal water balance of intake, diet, feeding pattern, and slaframine. J. Dairy Sci. 72:443-452.

Kalscheur, K. F., R. L. Baldwin, B. P. Glenn, and R. A. Kohn. 2006. Milk production of dairy cows fed differing concentrations of rumen-degraded protein. J. Dairy Sci. 89:249-259.

Kononoff, P. J., A. J. Heinrichs, and D. R. Buckmaster. 2003. Modification of the Penn State forage and total mixed ration separator and the effects of moisture content on its measurements. J. Dairy Sci. 86:1858-1863.

Ledoux, D. R., J. E. Williams, and T. E. Stroud. 1985. Influence of forage level on passage rate, digestibility and performance of cattle. J. Anim. Sci. 61:1559-1566.

Li, C., J. Q. Li, K. A. Beauchemin, and W. Z. Yang. 2012. Forage proportion and particle length affects the supply of amino acids in lactating dairy cows. J. Dairy Sci. 95:2685-2696.

Licitra, G. T. M. Hernandez, and P. J. Van Soest. 1996. Standardization of procedures for nitrogen fractionation of ruminant feeds Anim. Feed Sci. Technol. 57:347-358.

Littell, R. C., G. A. Milliken, W. W. Stroup, R. D. Wolfinger, and O. Schabenberger. 2006. SAS for Mixed Models. 2nd ed. SAS Institute Inc., Cary, NC.

Mjoun, K., K. F. Kalscheur, A. R. Hippen, and D. J. Schingoethe. 2010. Performance and amino acid utilization of early lactation dairy cows fed regular or reduced-fat distillers grains with solubles. J. Dairy Sci. 93:3176-3191.

Mould, F. L., R. Morgan, K. E. Kliem, and E. Krystallidou. 2005 A review and simplification of the in vitro incubation medium. Anim. Feed Sci. Technol. 123-124:155-172.

Neal, K., J.-S. Eun, A. J. Young, K. Mjoun, and J. O. Hall. 2014 Feeding protein supplements in alfalfa hay-based lactation diets improves nutrient utilization, lactational performance, and feed efficiency of dairy cows. J. Dairy Sci. 97:7716-7728.

NRC. 2001. Nutrient Requirements of Dairy Cattle. 7th ed. Natl Acad. Sci., Washington, DC.

Oba, M., and M. S. Allen. 1999. Evaluation of the importance of the digestibility of neutral detergent fiber from forage: Effect on dry matter intake and milk yield of dairy cows. J. Dairy Sci. 82:589596.

Ordway, R. S., S. E. Boucher, N. L. Whitehouse, C. G. Schwab, and B. K. Sloan. 2009. Effects of providing two forms of supplemental methionine to periparturient Holstein dairy cows on feed intake and lactational performance. J. Dairy Sci. 92:5154-5166.

Penner, G. B., M. Taniguchi, L. L. Guan, K. A. Beauchemin, and M. Oba. 2009. Effect of dietary forage to concentrate ratio on volatile fatty acid absorption and the expression of genes related to volatile 
fatty acid absorption and metabolism in ruminal tissue. J. Dairy Sci. 92:2767-2781.

Robertson, J. B., and P. J. Van Soest. 1981. The detergent system of analysis and its application to human foods. Pages $123-158$ in The Analysis of Dietary Fiber in Food. W. P. T. James and O. Theander, ed. Marcel Dekker Inc., New York, NY.

Sabbia, J. A., K. F. Kalscheur, A. D. Garcia, A. M. Gehman, and J. M. Tricarico. 2012. Soybean meal substitution with a yeastderived microbial protein source in dairy cow diets. J. Dairy Sci. 95:5888-5900.

Santos, F. A. P. J. E. P. Santos, C. B. Theurer, and J. T. Huber. 1998. Effects of rumen-undegradable protein on dairy cow performance: A 12-year literature review. J. Dairy Sci. 81:3182-3213.

Satter, L. D., and L. L. Slyter. 1974. Effect of ammonia concentration on rumen microbial protein production in vitro. Br. J. Nutr. 32:199-208.

Schwab, C. G., C. K. Bozak, N. L. Whitehouse, and M. M. A. Mesbah. 1992. Amino acid limitation and flow to duodenum at four stages of lactation. 1. Sequence of lysine and methionine limitation. J. Dairy Sci. 75:3486-3502.

Seo, S., H. J. Kim, S. Y. Lee, and J. K. Ha. 2008. Nitrogen utilization of cell mass from lysine production in goats. Asian-Australas. J. Anim. Sci. 21:561-566.

Shreve, B., N. Thiex, and M. Wolf. 2006. NFTA method 2.1.4-Dry matter by oven drying for 3 hours at $105^{\circ} \mathrm{C}$. NFTA Reference Methods. National Forage Testing Association, Omaha, NE Accessed Mar. 19, 2015. http://www.foragetesting.org/files/ NFTAReferenceMethodDM-09-18-06.pdf.

Taylor-Edwards, C. C., G. Hibbard, S. E. Kitts, K. R. McLeod, D. E. Axe, E. S. Vanzant, N. B. Kristensen, and D. L. Harmon. 2009. Effects of slow-release urea on ruminal digesta characteristics and growth performance in beef steers. J. Anim. Sci. 87:200-208.

Trinder, P. 1969. Determination of glucose in blood using a glucose oxidase with an alternative oxygen acceptor. Ann. Clin. Biochem. $6: 24-27$.
USDA-ERS. 2015. Monthly cost of production estimates. USDAEconomic Research Service, Washington, DC. Accessed Jun. 22 , 2015. http://www.ers.usda.gov/data-products/milk-cost-ofproduction-estimates.aspx.

Van Soest, P. J. 1963. Use of detergents in the analysis of fibrous feeds. II. A rapid method for determination of fiber and lignin. J. Assoc. Off. Agric. Chem. 46:829-835.

Van Soest, P. J., J. B. Robertson, and B. A. Lewis. 1991. Methods for dietary fiber, neutral detergent fiber, and nonstarch polysaccharides in relation to animal nutrition. J. Dairy Sci. 74:3583-3597.

Weatherburn, M. 1967. Phenol-hypochlorite reaction for determination of ammonia. Anal. Chem. 39:971-973.

Wildman, E. E., G. M. Jones, P. E. Wagner, R. L. Boman, H. F Troutt, and T. N. Lesch. 1982. A dairy cow body condition scoring system and its relationship to selected production characteristics. J. Dairy Sci. 65:495-501.

Yang, W. Z., and K. A. Beauchemin. 2004. Grain processing, forageto-concentrate ratio, and forage length effects on ruminal nitrogen degradation and flows of amino acids to the duodenum. J. Dairy Sci. 87:2578-2590.

Yang, W. Z., and K. A. Beauchemin. 2007. Altering physically effective fiber intake through forage proportion and particle length: Chewing and rumen pH. J. Dairy Sci. 90:2826-2838.

Yang, W. Z., and K. A. Beauchemin. 2009. Increasing physically effective fiber content of dairy cow diets through forage proportion versus forage chop length: Chewing and ruminal $\mathrm{pH}$. J. Dairy Sci. 92:1603-1615

Yeo, J.-M., C. H. Knight, and D. G. Chamberlain. 2003. Effects of changes in dietary amino acid balance on milk yield and mammary function in dairy cows. J. Dairy Sci. 86:1436-1444. 